\title{
Analysis of Proximate Principles of Feeds and Fodders
}

\author{
N.R. Sonone ${ }^{1 *}$, S.D. Chavan ${ }^{1}$ and M.U. Tanpure ${ }^{2}$ \\ ${ }^{1}$ Department of Animal Husbandry and Dairy Science, Dr. P.D.K.V., Akola, India \\ ${ }^{2}$ Department of Animal Husbandry and Dairy Science, V.N.M.K.V. Parbhani, India
}

*Corresponding author

\section{A B S T R A C T}

\begin{tabular}{|l|}
\hline Ke y w o r d s \\
$\begin{array}{l}\text { Proximate principles, } \\
\text { Feeds and fodders }\end{array}$ \\
\hline Article Info \\
\hline $\begin{array}{l}\text { Accepted: } \\
\text { 06 July } 2018 \\
\text { Available Online: } \\
\text { 10 August } 2018\end{array}$ \\
\hline
\end{tabular}

\section{Introduction}

India is an agricultural country and livestock plays an important role in Indian agriculture. Animal Husbandry forms the backbone of rural economy and also it has been understood that of the total cost of milk production (70percent) is attributed to feeding alone.

Balanced feeding is another necessity. It has been observed that animal in certain region are suffering from various mineral disease. These are instances, where animal do not grow and perform well even after feeding the adequately due to nutritional imbalance. Therefore it is beneficial to analyze available feed and fodder and prepare a feed schedule, balancing the entire beneficial nutrient. Effort in planned feeding of the animals will not only enhance the production and profit but also reduce feed shortage.

The result of the present study will definitely helpful for judicious feeding to the animal on one hand and maintaining their productivity on other hand. Considering this aspect it seen necessary to utilize the fodder resources.

\section{Materials and Methods}

The present investigation was undertaken at Livestock Instructional Farm, of Animal Husbandry and Dairy Scince Department of Dr. Panjabrao Deshmukh Krishi Vidyapeeth, Akola during the year 2015-2016. Jowarkadbi, Soybean straw, hybrid Napier as green fodder and Sugras dry ration as concentrate mixture were analysed. 
Dry matter, crude protein, crude fiber, nitrogen free extract and total ash were determined as per procedure given in Bureaus of Indian standard (1990).

\section{Dry matter}

The dry matter percentage was determine as per the procedure recommended by BIS, IS: 7874(part-I)-1975.

Weighted accurately $100 \mathrm{~g}$ of the feed and fodder in to aluminum dish. Heated the dish containing the material in hot air oven maintained at $100-120^{\circ} \mathrm{C}$ for about 3 hours cooled it and weighted with the cover on. Repeated the process of drying cooling and weighting at 30 minutes intervals for appropriate reading.

Moisture percent by weight $=\frac{100\left(\mathrm{~W}_{1-} \mathrm{W}_{2}\right)}{\mathrm{W}_{1}-\mathrm{W}_{2}}$

Dry matter $(\%)=$ Weight of sample - weight of moisture in sample

Where,

$\mathrm{W}_{1}=$ Weight of gram of the dish with feed before drying

$\mathrm{W}_{2}=$ Weight in gram of the dish with feed after drying

\section{Crude protein}

Nitrogen percentage was estimated by Kjeldahl's method as per the procedure recommended by BIS, IS: 7475(part I)-1975 and crude protein percentage was calculated by multiplying the percentage of total nitrogen by 6.25. After determining the moisture content, the oven dried sample was ground and further processed for chemical analysis. Weighed $10 \mathrm{~g}$ of sample was transferred to the
Kjeldahl's flask. About $10 \mathrm{~g}$ of potassium sulphate and $0.5 \mathrm{~g}$ of copper sulphate were added to flask $25 \mathrm{ml}$ of concentrated sulphuric acid was added. The flask was plays on digestion chamber and heated gently to boil until contents were clear and allowed the liquid to cool and diluted with $200 \mathrm{ml}$ of distilled until all ammonia was passed over and was received over standard sulphuric acid which was then back titrated with standard $\mathrm{NaOH}$ in order to determine the amount of standard acid used to neutralize the ammonia evolved from digested material. Similarly bland sample was run.

Total nitrogen $(\%)=\frac{1.4(\mathrm{~B}-\mathrm{A}) \mathrm{N}}{\mathrm{W}}$

Total protein $=$ total nitrogen $X 6.25$

Where,

$\mathrm{B}=$ Volume of $\mathrm{N} / 10 \mathrm{NaOH}$ for blank

$\mathrm{A}=$ Volume of $\mathrm{N} / 10 \mathrm{NaOH}$ used for sample

$\mathrm{N}=$ Normality of standard $\mathrm{NaOH}$

$\mathrm{W}=$ Weight of sample in $\mathrm{g}$

\section{Crude fiber}

Crude fiber percentage will be determined as per the procedure recommended by BIS, IS: 7874(part)-1975.

After determining ether, the oven dried sample was ground $10 \mathrm{~g}$ of sample was transferred into a flask and boiled with $1.25 \%$ sulphuric acid $1.25 \%$ sodium hydroxide for half an hour. Then left residue was dried, weighted and ignited. Loss in weight was taken as fiber contents of the sample.

\section{Total ash}

Total ash was estimated as per the procedure recommended by BIS, IS: 7874(part I) -1975. 
The empty and dried silica crucible was weighed. Accurately $10 \mathrm{~g}$ of feed sample was taken. The sample was evaporated to dryness on a hot plate. The crucible was placed in a pre-heated Muffle furnace and heated the contents at $550-600^{\circ} \mathrm{C}$ until ash was free carbon. The crucible was cooled by placing in desiccators.

Percent ash by weight $=\mathrm{B} / \mathrm{A} X 100$

Where,

$A=$ Weight of feed sample

$\mathrm{B}=$ Weight of ash

\section{Nitrogen free extract}

NFE was estimated as per the BIS, IS: 7874 (part I)-1975.

The sum of all (i.e. Moisture Crude Fiber, Ether Extract and Total Ash) was subtracted from the percentage of total nutrients.

Nitrogen free extract $(\%)=100-(A+B+C+$ $\mathrm{D}+\mathrm{E})$

Where,

$\mathrm{A}=$ Moisture content $(\%)$

$\mathrm{B}=$ Crude Protein $(\%)$

$\mathrm{C}=$ Ether extract $(\%)$

$\mathrm{D}=$ Crude fiber $(\%)$

$\mathrm{E}=$ Ash content $(\%)$

\section{Results and Discussion}

From the Table it was observed that jowarkadbi, soybean straw, hybrid Napier and concentrate were containing 90.23, 87.62, 29.75 and 91.12 DM respectively. The jowarkadbi was containing 3.74, 2.84, 51.52, 32.48 and 9.42 per cent CP, EE, NFE, CF and ash while soybean straw was containing 6.13 , 2.51, 37.29, 44.21, 9.86 per cent, CP, EE, NFE, CF and ash respectively. The contents of nutrients in hybrid Napier was 5.77, 2.50, 49.22, 26.28 and 16.23 per cent CP, FE, NFE, $\mathrm{CF}$ and Ash. Similarly the contents of nutrient in concentrate were $17.34,5.27,61.74,11.84$ and 3.81 per cent CP, EE, NFE, CF and ash.

The chemical composition reported by Jhori et al., (1971), Pachauri and Negi (1976) and Gupta et al., (1978) for soybean straw are in the line with the present values. They reported protein value from 4.90 to $6.58 \%$. The present value falls between the reported values. The variation in the protein content of the straw might be on account of incorporation of cut and low graded soybean grains during threshing process and the proportion of the grains would influenced the $\mathrm{CP}$ content of the by products.

The most significant finding was that soybean straw twice rich as that of jowar in respect of CP content. Similarly, CF was higher in soybean straw than that of jowarkadbi, whereas NFE, EE and Ash were higher in jowarkadbi, over soybean straw.

Chemical composition of jowarkadbi is nearer with that of reported by Ibrahim et al., (1998). They also observed that the content of $\mathrm{CP}, \mathrm{CF}$, $\mathrm{EE}$ and NFE in jowarkadbi as 4.04, 37.34, 2.40 and 4.55 per cent respectively, slightly lower values of $\mathrm{CP}$ and $\mathrm{CF}$, but the values of $\mathrm{EE}$ and NFE are in line with present value. The difference in value of $\mathrm{CP}$ and $\mathrm{CF}$ is due to change in variety, soil climatic condition and harvesting time of jowar. Similar observations were also noted by kamble (2006) and Bansod (2008).

Moreover Gampawar and Zinzarde (1992) noted change in the composition of jowar at different maturity stage, $\mathrm{CP}$ being highest at boost stage followed by $50 \%$ flowering stage $(7.20 \%)$ and milky stage (4.40\%) these observations support the present trend in respect of proximate principle of jowarkadbi. 


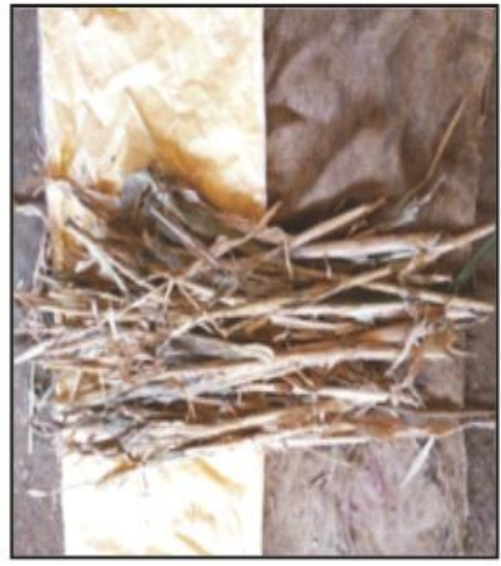

Jowar Kadbi

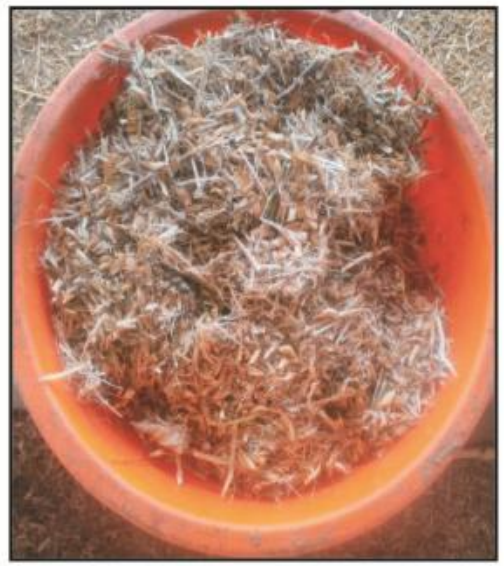

Soybean straw

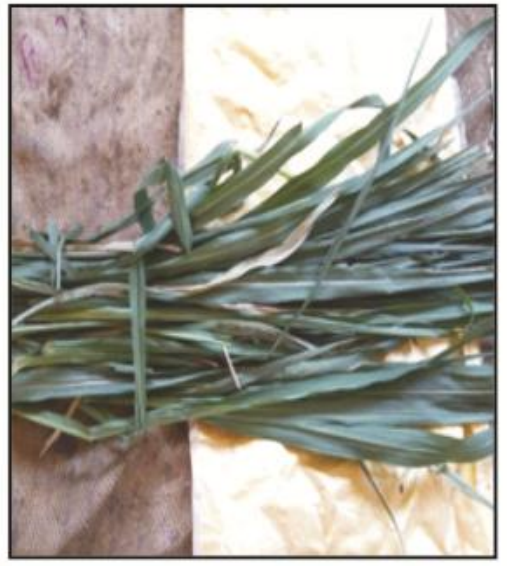

Green Napier

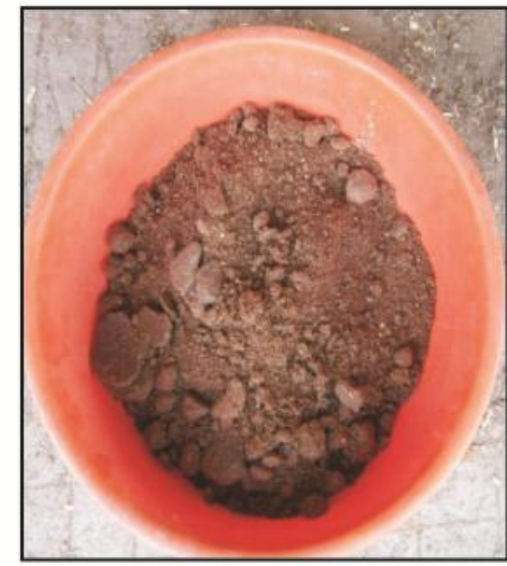

Concentrate

Plate 1: Feed stuff

Chemical composition of feed stuffs (on \% DM)

\begin{tabular}{|c|c|c|c|c|}
\hline Particulars & Jowarkadbi & $\begin{array}{c}\text { Soybean } \\
\text { Straw }\end{array}$ & $\begin{array}{c}\text { Hybrid Napier } \\
\text { (Green } \\
\text { fodder) }\end{array}$ & $\begin{array}{c}\text { Concentrate } \\
\text { (Sugras dry } \\
\text { ration) }\end{array}$ \\
\hline DM & 90.23 & 87.62 & 29.75 & 91.12 \\
\hline CP & 3.74 & 6.13 & 5.77 & 17.34 \\
\hline EE & 2.84 & 2.51 & 2.50 & 5.27 \\
\hline NFE & 51.52 & 37.29 & 49.22 & 61.74 \\
\hline CF & 32.48 & 44.21 & 26.28 & 11.84 \\
\hline Total Ash & 9.42 & 9.86 & 16.23 & 3.81 \\
\hline
\end{tabular}


Green Hybrid Napier contained 29.75\% DM Along with 5.77, 2.50, 49.22, 26.28 and 16.23 per cent $\mathrm{CP}, \mathrm{FE}, \mathrm{NFE}, \mathrm{CF}$ and total Ash on dry matter basis, respectively. The present $\mathrm{CP}$ values are nearer with the composition reported by Talpada (1978) as 5.89\%, Parnekar et al., (1985) as 4.30\%, Bansod (2008) as $5.77 \%$ and Kumaresan and Parthasarathy (2008) $7.8 \%$ are substantially higher than the present value.

Higher or lower CP content in hybrid Napier as $13.5 \%$ reported by Balaraman (1995), which appears to be substantially higher than the present value.

Higher or lower CP content in Hybrid Napier might be on account of differences in the variety and stage of harvesting according to Reddy and Reddy (1986). The noted further the increase in the content of DM, CF, Lignin and Silica to the extent of 40 to $46 \%$ and decrease in CP level by $60 \%$ at 14 to 15 weeks harvest stage in comparison to 8 to 9 weeks harvest stage.

Concentrate mixtures, a product of Maharashtra Agro Industries Development Corporation MAIDC, under the trade name "Sugras" was containing 18.45 and $11.18 \%$ $\mathrm{CP}$ and $\mathrm{CF}$ on DM basis, respectively. Moreover the past workers like Bohra et al., (1987), Puri and Gupta (2001) and Gupta and Murdia (2006) also suggested feeding of higher CP level concentrates (19.5 to $19.8 \%$ ) while rearing animals on ammonia treated paddy and wheat straw. Kamble (2006) and Adangale et al., (2009) reported the CP content of Sugras between 17.34 to $19.17 \%$ which is comparable with present results.

\section{References}

Adangale, S. B., K. R. Mitkari, T. R. Walkunde, S. V. Baswade 2009. Effect of feeding jowar straw in combination with soybean straw on the growth performance of crossbred calves. Indian Journal of Animal Research. 43 (1): 142-144.

Balaraman, N. 1995. Nutrtive value of hybrid napiergrass. India J.Anim.Nutr. 12(4): 245-246

Bansod, P. H. 2008. Nutritional requirement of gaolao cow. M. Sc. (Agri.) Thesis (Unpub.) Submitted Dr. P. D. K. V. Akola.

Ibrahim, P. M., P. C. Shukla and U.P. Mehra 1998. Compared the nutritive value of jowar straw with that of wheat bhoosa. Livestock Advisor. 19 (11): 119-123.

Jhori, C.B., S.K. Kulshreshtra and J.S. Saxena 1971. Chemical composition and nutritive value of green soybean and soybean straw. Indian Vet. J. 48(7): 938-940.

Kamble, D. M. 2006. Effect of feeding soybean straw on quality of milk of crossbred cows. M. Sc. (Agri.) Thesis (Unpub.), Dr. P D. K. V. Akola.

Kumarasan R. And M. Parthasarthy, 2008. Utilization of nutrient from Bajra Napier. G.N. Naulms or Sibabul leaves as sole feeds by growing sheep. Indian J.Anim.Nutr., 25(2), 142-152

Pachauri, V.C. and S.S. Negi 1976. Nutritive value of soybean straw (bhoosa). Indian J. Anim. Sci. 46(3): 118-121

Parnekar, S., P.M. Desai, J.M. Patel and A.O. Dave 1985. Nutritive value of hybrid naiper and shevri leaves silage for sheep. Indian J.Anim.Nutr. 2(4): 175177

Puri, J. P. and B. N. Gupta 2001. Effect of feeding rice straw treated with two levels of urea and moisture on growth and nutrient utilization in crossbred heifer. Indian J. Anim. Nutr. 18 (1): 5459. 
Reddy, G.J and B.S. Reedy 1986, Nutritive value of ratoon regrown Hybrid Napier (NB-21). Indian J. Anim. Nutri., 32: $128-131$

Talpada, P.M; L.P. Purohit, H.D. Desai and P.C. Shukla 1978. Comparative studies on the nutritive value of Hybrid Napier fodder as green, silage and hay. Indian J. Anim. Sci. 48(8): 563-565

\section{How to cite this article:}

Sonone, N.R., S.D. Chavan and Tanpure, M.U. 2018. Analysis of Proximate Principles of Feeds and Fodders. Int.J.Curr.Microbiol.App.Sci. 7(08): 678-683.

doi: https://doi.org/10.20546/ijcmas.2018.708.073 